\title{
Interactive comment on "Exploring global surface temperature pattern scaling methodologies and assumptions from a CMIP5 model ensemble" by Cary Lynch et al.
}

\section{T.J. Osborn (Referee)}

t.osborn@uea.ac.uk

Received and published: 13 September 2016

The comment was uploaded in the form of a supplement:

http://www.geosci-model-dev-discuss.net/gmd-2016-170/gmd-2016-170-RC3-

supplement.pdf

Interactive comment on Geosci. Model Dev. Discuss., doi:10.5194/gmd-2016-170, 2016. 